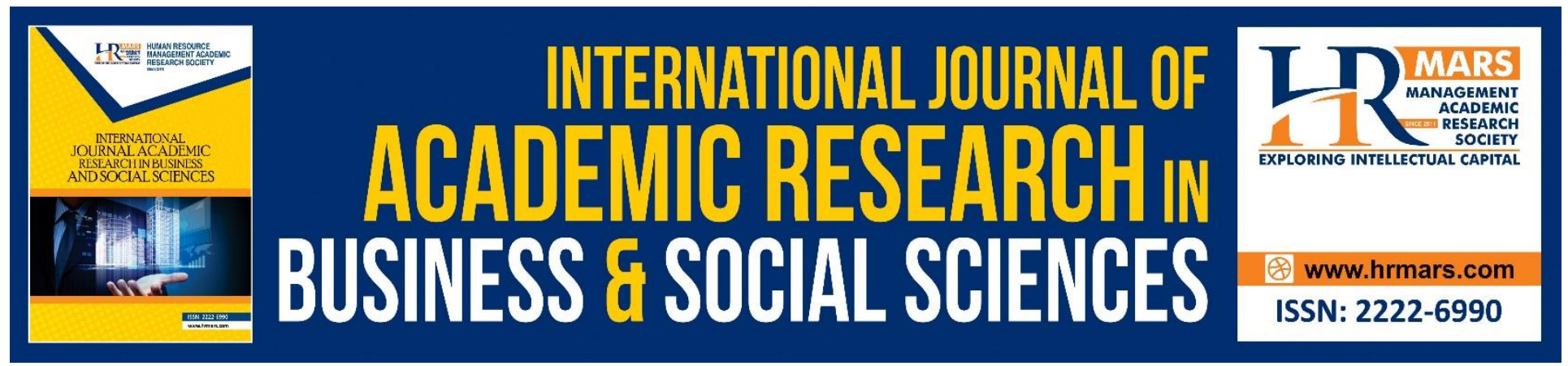

\title{
Simulation of Electronic Circuit for Design and Technology Subject in Secondary Schools
}

\author{
Abu Bakar Ibrahim, Faridah Hanim Yahya, Hafizul Fahri Hanafi, \\ Nurul Hsaniah Omar
}

To Link this Article: http://dx.doi.org/10.6007/IJARBSS/v9-i2/5581

DOI: $\quad 10.6007 /$ IJARBSS/v9-i2/5581

Received: 08 Jan 2019, Revised: 11 Feb 2019, Accepted: 18 Feb 2019

Published Online: 24 Feb 2019

In-Text Citation: (Ibrahim, Yahya, Hanafi, \& Omar, 2019)

To Cite this Article: Ibrahim, A. B., Yahya, F. H., Hanafi, H. F., \& Omar, N. H. (2019). Simulation of Electronic Circuit for Design and Technology Subject in Secondary Schools. International Journal of Academic Research in Business and Social Sciences, 9(2), 477-486.

Copyright: (C) 2019 The Author(s)

Published by Human Resource Management Academic Research Society (www.hrmars.com)

This article is published under the Creative Commons Attribution (CC BY 4.0) license. Anyone may reproduce, distribute, translate and create derivative works of this article (for both commercial and non-commercial purposes), subject to full attribution to the original publication and authors. The full terms of this license may be seen at: http://creativecommons.org/licences/by/4.0/legalcode

Vol. 9, No. 2, 2019, Pg. 477 - 486

Full Terms \& Conditions of access and use can be found at http://hrmars.com/index.php/pages/detail/publication-ethics 


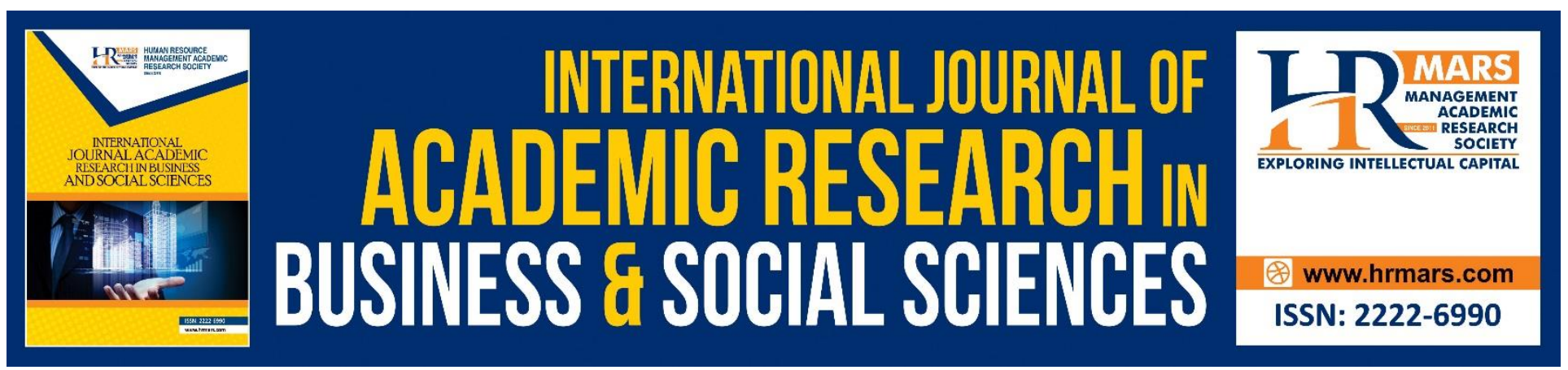

\title{
Simulation of Electronic Circuit for Design and Technology Subject in Secondary Schools
}

\author{
Abu Bakar Ibrahim¹, Faridah Hanim Yahya², Hafizul Fahri Hanafi³, \\ Nurul Ihsaniah Omar ${ }^{4}$
}

Universiti Pendidikan Sultan Idris, Malaysia

\begin{abstract}
In education, the use of simulation of electronic circuit is very helpful in the process of teaching and learning. Therefore, majority of engineering colleges, universities, and technical institutions are undertaking all initiatives to stay competitive. Effort are exerted to continuously improve the curriculum standard in order to provide quality and relevant education for the students in response the global call for Outcomes-Based Education (OBE). This paper presents the simulation of electronic circuit for Design and Technology Subject in Secondary Schools. Livewire Designer Software is a schematic capture, simulation, and PCB design software, dedicated to analyzing electronic circuit which is based on interconnected icons of electronic component. The approach makes it easier for the students to visualize the system they are attempting to design, model and study.
\end{abstract}

Keywords: Simulation, Livewire, Design and Technology

\section{Introduction}

Information and Communication Technology (ICT) technology covers all technologies that help disseminate information such as radio, television, mobile phones, computers and the internet. This has affected the education and its impact can be divided into three phases namely the replacement phase, transition phase and phase of change. In the replacement phase, teachers make them as a tool for teaching and learning sessions without changing teaching methods, while in the transition phase, teachers use ICT that can stimulate changes to new teaching methods. For the phase of change, it involves a fundamental change in the role of students and teachers in teaching and learning. The rapid development of information and communication technology affects almost all aspects of life including education. Developments in technology have also changed the way people learn. In addition, the learning process has now surpassed the physical space of the classroom, being globalized and lifelong. As such, the education system in Malaysia is also influenced by this, especially in relation to ICT applications in teaching and learning (Hadjerrouit,2008). The world is in the digital era where the source of knowledge is the pulse and backbone of the success of a nation especially in 
education. Therefore, traditional teaching styles also need to be upgraded. Recent system hardware modules and software program tools for electronics, microprocessors, and microelectronics are now being used in classrooms and laboratories to provide effective and efficient way of teaching the technical subject in design and technology. These tools are considerably of great help for lecturers whose purpose is to get the message across the students in an accurate and precise manner. These tools give the students a sense of awareness of what to use when they go out and work in their respective fields (Abdullah, et. al., 2011).

\section{Literature Review}

Education has an important role in developing a country to ensure the sustainability of a society. Through education, quality energy sources can be produced. By the way, education and technology are mutually dependent and inseparable. The use of media and technology is an interactive learning. Students do not just use paper and stationery to present their understanding of modules or subjects learned even more when technology is applied in education. According to Andrew 2000, traditional or conventional teaching methods that practice in teaching and learning today will not be able to meet the demands of the 21st century education. Learning is no longer focused on the classroom alone, but teaching methods are also evolving as technology develops in Malaysia. For example, traditional textbooks can not cope with the ups and downs of information that are in line with the era of circulation. The use of technology in the field of education should not be subject to limitations or constraints that may impede the teaching and learning process. Therefore, constraints in the information and communications technology infrastructure at schools or institutions of higher learning should be addressed immediately. Quality education can produce good student output or output. According to Silvia 2011, lack of infrastructure in education and other factors such as background and socioeconomic of student families, individual student developments, and other physical and social environments may be an obstacle for an individual to succeed in education and his life. Starting with learning and learning methods using blackboard and chalk turned to the use of technology namely computers, electronic materials, Liquid Crystal Display (LCD), video cameras and the latest smart-phone applications used in the study rooms. From time to time, education through changes is in line with the advancement of thought, will and teaching technology.

Lack of reference material for learning is one of the causes for a student's misunderstanding of what is learned. This is because the reference material can be used as a guide by students in understanding the lessons learned. In the absence of a reference material, students are less likely to understand what they are learning. Utusan Malaysia reports that reference material is important as it is an added value to the learning notes given by teachers. In fact, this reference material has the latest information that can help students when reviewing the lessons. Indeed, students are encouraged to make a reference so that all new information is obtained immediately. There are a number of benefits or advantages in using educational software in teaching and learning process. These benefits are of paramount important in maintaining a good momentum of reading interest among students in ICT. Use of computers and software ICT tools in classrooms and laboratories, provide much more effective and efficient environments in teaching and learning, making living skills easier to understand. The advantages of using simulation software in conjunction with classroom teaching are 
well known. It is generally acceptable that the use of interactive teaching tools, which provide instant feedback to the student's inputs, improve and accelerate the learning process (Melor et.al., 2013).

The use of simulation and ICT tools secondary education is not a new concept. However, the traditional teaching methodology used in secondary education is based mainly on oral speech and use of blackboard. In line with a number of researchers in ICT education, teaching approaches that are based on the understanding of software principles for problem solving involve three major components. It is important to generate understanding using situated examples, visualizations, and dialogues. By using situated examples, the teacher should enable the students to understand the software problem. The principles of the software are then explained through visualizations. Finally, the teacher gives the right sequence of software instructions showing the main implementation steps of the problem solving process. Students use software principles to construct solutions to the problem through involvement in realistic task-based activities. The goal is for students to construct their knowledge and to work at their own pace from their prerequisites (Guilina, et.al, 2002).

The teacher works as a mentor and guide of learning rather than as a transmitter of knowledge. Students get the opportunity to raise questions regarding the specific problem solving process or more general problems related to software use. Students might for example discuss how the software could be used in similar situations. The teacher can then provide supplementary information. The advantages offered by the educational software include unconventional tests allowing for an optimal feedback, user-friendly working environments, individual or team work, stimulation of the creativity and of the competition spirit by pursue of different modules, visual support which gives rapid understanding of even the most subtle and complex scientific themes. For a more intense involvement of each student into the learning process, the educational software provides animation and the possibility to replay. This kind of activities allow the student to learn by playing, by varying different parameters and quantities in a rigorous, mathematical way, because mathematics, creativity, logic, and originality are all needed to improve technology (Brodahl, et.al, 2007).

\section{LIVEWIRE DESIGNER SOFTWARE}

Livewire is a sophisticated software package for designing and simulating electronic circuits. Switches, transistors, diodes, integrated circuits and hundreds of other components can all be connected together to investigate the behavior of a circuit. There are no limits to what can be designed and no loose connections or faulty components to worry about. Livewire also direct user interface helps you to build circuits quickly and easily. Just grab the components you need and connect them together using Livewire intelligent wiring tool. Make any final adjustments to your circuit by moving components. Figure 1, shown a screenshot of getting started of Livewire Software. 


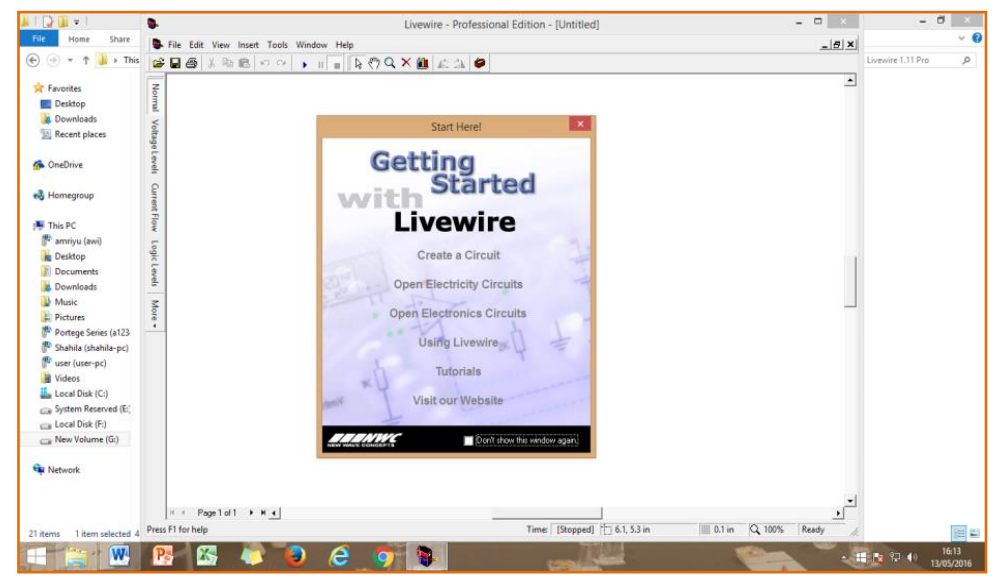

Fig. 1 - A screen shot from the liveware educational software.

\section{SIMULATION AND RESULTS}

Simulation is mathematical models to replicate the behavior of an actual electronic device or circuit. Simulation software allows for modeling of circuit capability, many colleges and universities use this type of software for teaching of electronic subject. Livewire Designer Software is design for the purpose of changing the attitude of the students in learning electronic circuit. It is a challenge for the student and effective in preparation for their career in R \& D field in electronic. The use of Livewire Designer Software shall greatly reduced unnecessary task in setting up and performing circuit analysis without suffering too much for the accuracy and correctness of the output. The major advantage of software to computer programming is the whole system can be easily visualized and debugging is similar to the actual electronic circuit design of the system (Bakar et. al, 2017).

The computer's graphic capabilities make them useful in designing devices and in simulating complicated processes. This educational software is entirely interactive. It's main plus is the quality which included the actual devices, component and measurement equipment's. For Example, an DC power as a rectifier to convert AC into DC. DC power supply is important element of any electronic equipment. This is because it provides power to energize all electronic circuit like oscillators, amplifier and so on. In electronic equipment, DC power supply is must. The reliability and performance of the electronic system proper design of power supply is necessary. The students can see the process that occurs by using an oscilloscope available in the library. After click button "Run" this circuit, will be appear the output and the output signal. For a better understanding of the phenomenon, the simulation can be paused at any moment. Figure $2(a)$ and (b) shows the half wave rectifier circuit and output. In half wave rectifier only half cycle of Applied AC voltage is used. Another half cycle of AC voltage (Negative Cycle) is not used. Only one diode is used which conducts during positive cycle (Umarani, 2010). 


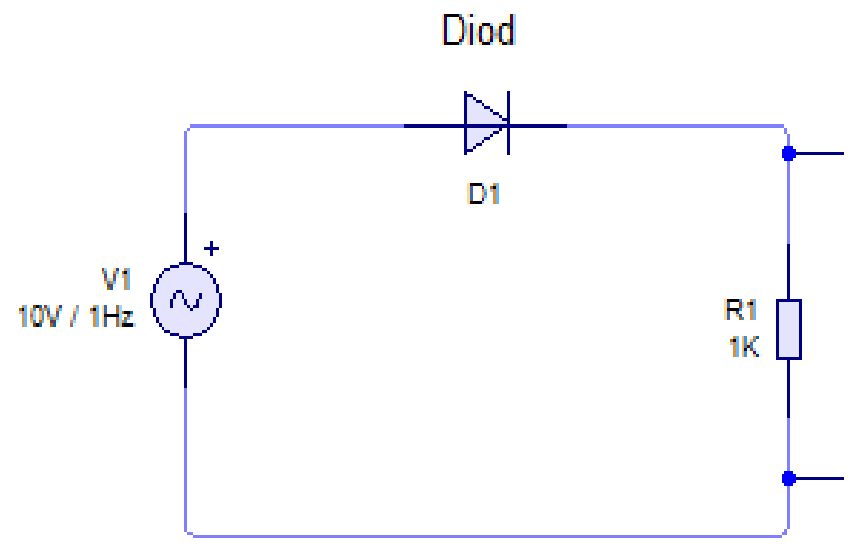

Figure 2(a): Half Wave Rectifier Circuit

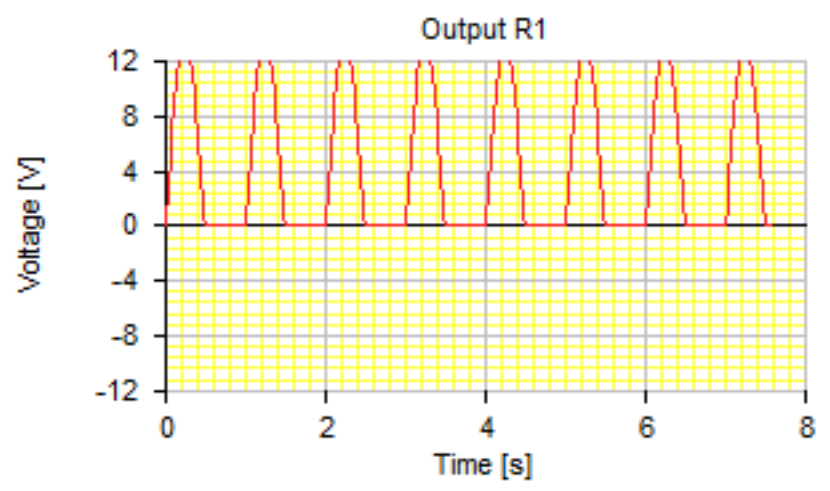

Figure 2(b): Output of Half Wave Rectifier Circuit

Figure 3(a) and (b) shows the full wave rectifier and output. The primary winding of the center tap transformer is applied with the Ac voltage. Thus the two diodes connected to the secondary of the transformer conducts alternatively. For the positive half cycle of the input diode D1 is connected to the positive terminal and D3 is connected to the negative terminal. Thus diode D1 is in forward bias and the diode D3 is reverse biased. Only diode D1 starts conducting and thus current flows from diode and it appears across the load RL. So positive cycle of the input is appeared at the load. During the negative half cycle the diode D3 is applied with the positive cycle. D3 starts conducting as it is in forward bias. The diode D1 is in reverse bias and this does not conduct. Thus current flows from diode D3 and hence negative cycle is also rectified, it appears at the load resistor RL. 


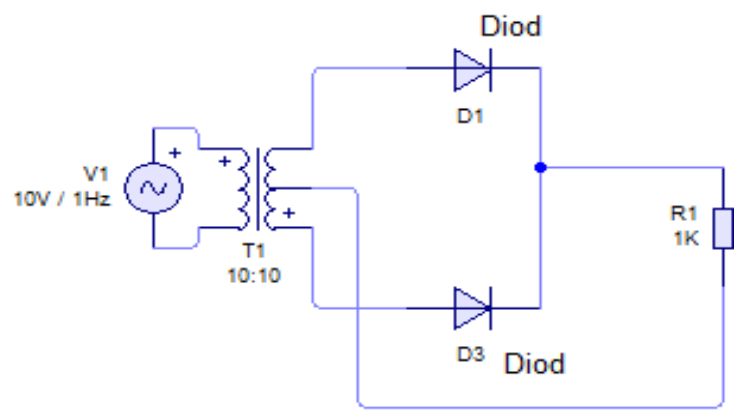

Figure 3(a): Full Wave Rectifier Circuit

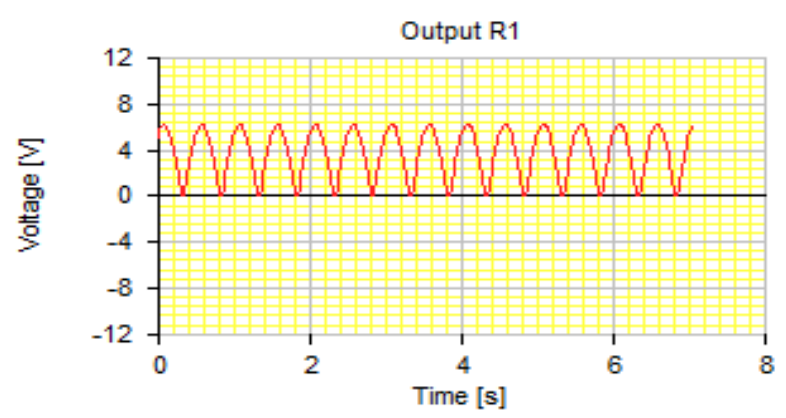

Figure 3(b): Output of Half Wave Rectifier Circuit

Another type of circuit that produces the same output waveform as the full wave rectifier circuit above, is that of the Full Wave Bridge Rectifier. This type of single phase rectifier uses four individual rectifying diodes connected in a closed loop "bridge" configuration to produce the desired output. The main advantage of this bridge circuit is that it does not require a special centre tapped transformer, thereby reducing its size and cost. The single secondary winding is connected to one side of the diode bridge network and the load to the other side as shows in Figure 4(a) and (b) respectively (Hennessy, et. al.,2010). 


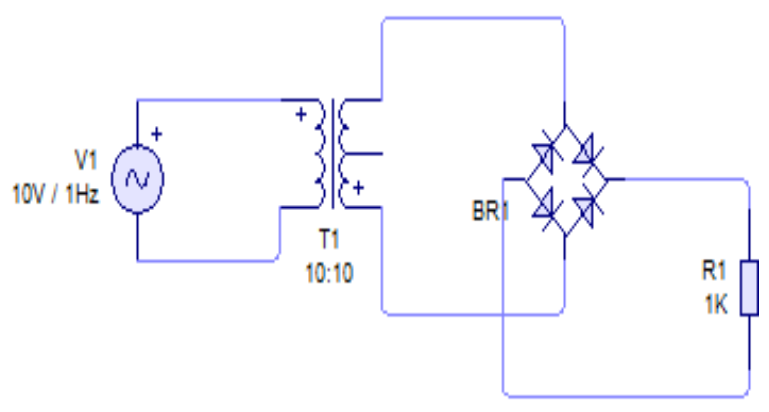

Figure 4(a): Full Wave Rectifier Circuit (Bridge)

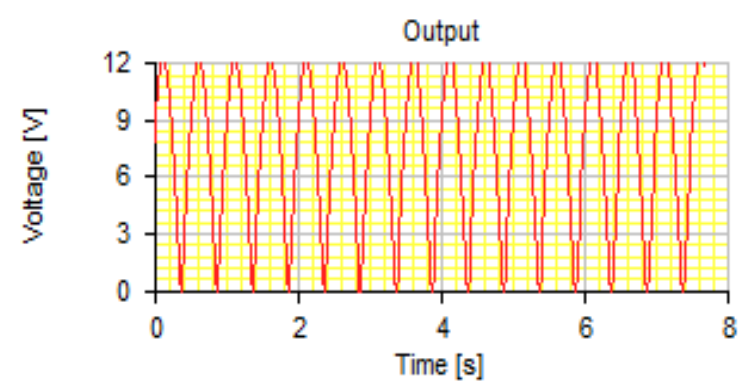

Figure 4(b): Output of Full Wave Rectifier Circuit (Bridge)

The previous section that the single phase half-wave rectifier produces an output wave every half cycle and that it was not practical to use this type of circuit to produce a steady DC supply. The fullwave bridge rectifier however, gives us a greater mean DC value with less superimposed ripple while the output waveform is twice that of the frequency of the input supply frequency. It can improve the average DC output of the rectifier while at the same time reducing the AC variation of the rectified output by using smoothing capacitors to filter the output waveform. Smoothing or reservoir capacitors connected in parallel with the load across the output of the full wave bridge rectifier circuit increases the average DC output level even higher as the capacitor acts like a storage device as shown in Figure 5(a) and (b) respectively (Angelo et. al, 2014)

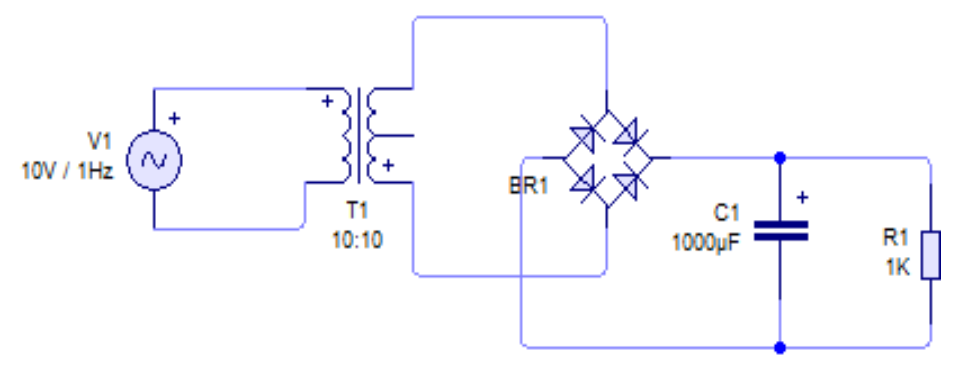

Figure 5(a): Full Wave Rectifier Circuit (Bridge) with Filter and Output 
INTERNATIONAL JOURNAL OF ACADEMIC RESEARCH IN BUSINESS AND SOCIAL SCIENCES Vol. 9, No. 2, Feb, 2019, E-ISSN: 2222-6990 C 2019 HRMARS

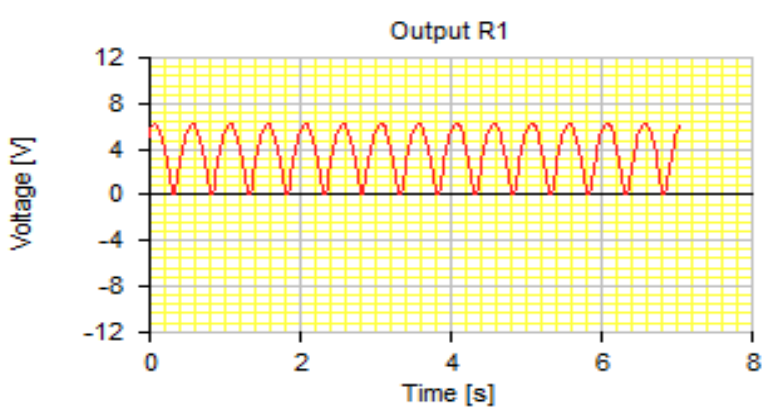

Figure 5(b): Output of Full Wave Rectifier Circuit (Bridge) with Filter

\section{Conclusion}

By using educational software, the student is provided with sequences, which can be lesson stages, tests, and so on. Through these sequences, there can access information (libraries, internet), can receive a mark, or can contact other students who work in the same environment. The teacher who has access to educational software can choose certain lesson stages which are in accordance with topics from the school curriculum, but there can also create sequences based on the feedback received from a certain group of students, or on the strategies that there uses. The greatest advantage is represented by the opportunity to receive feedback from all the students in the class who, in their turn, can work independently according to their level or abilities; thus, the educational process can be shaped directly on the group of students the teacher is working with, the flexibility and adaptability of the educational teaching content being a necessary conditions in order to improve the learning results. We propose this type of lesson based on interactive conveyance of information, and developing motivation and interactive learning skills. The student will learn by reading, discovering and solving numerous reasoning exercises which make reference to theoretical living skills concepts. Navigating through lessons is easy and intuitive. Each lesson contains a help section specific to that particular lesson (Yuan el. al,.2013).

\section{Corresponding Author}

Abu Bakar Ibrahim, Universiti Pendidikan Sultan Idris, Malaysia, Tanjung Malim, Perak Malaysia.

Email: abupsp@gmail.com

\section{Acknowledgement}

I would like to take this opportunity to thank the Research Management \& Innovation Centre (RIMC) of Sultan Idris Education University for Permitting and Supporting in this research (20180045-107-01) 
INTERNATIONAL JOURNAL OF ACADEMIC RESEARCH IN BUSINESS AND SOCIAL SCIENCES

Vol. 9, No. 2, Feb, 2019, E-ISSN: 2222-6990 C 2019 HRMARS

\section{References}

Moraru, S., Stoica, I., \& Popescu, F. F. (2011). Educational software applied in teaching and assessing physics in high schools. Romanian Reports in Physics, 63(2), 577-586.

Dettori, G. I. U. L. I. A. N. A., Ott, M., \& Tavella, M. A. U. R. O. (2002). Integrating the use of educational software in primary school teaching by shaping learning itineraries. Proceedings of ICTE2002, 1530-1536.

Bakar, A. (2017). "The application of educational software in Teaching and Learning for Living Skills in Secondary Schools". Proceeding in ITECP.

Pillai, S. \& Vengadasamy, R. (2010). “Developing Understanding and Appreciation of Literature and Critical Reading Concept Through Multi model Approaches". Malaysian Journal of ELT Research 6.

Brodahl, M. F. \& Hadjerrouit, S. (2007) “Applying and evaluating understanding-oriented ICT user training in upper secondary education". Issues in Informing Science and Information Technologies, 4, 473-490.

Kokol-Voljc, V. (2007). Use of mathematical software in pre-service teacher training: The case of dgs. Proceedings of the British Society for Research into Learning Mathematics, 27(3), 55-60.

Abdullah, T., Zakaria, M. H., Ismail, F., Adlina, W. F., \& Aziz, M. (2011). A New Teaching Model to Teach Literature for the Pre-Training Service Programme in Universiti Teknologi Malaysia. 2007. eprints. utm. my (Vol. 6). 3970/1/75167. pdf.

Yuan, L., Sheila. M., Kraan, W. (2013). Open Educational Resources Opportunities and challenges for High Education. JISC 2013.

Umarani, K. (2010). “Instruments \& Measurements”. IBS Buku Sdn.Bhd. 